Prepared in cooperation with Seattle City Light and Seattle Public Utilities

\title{
Streambed Scour of Salmon (Oncorhynchus spp.) and Steelhead (Oncorhynchus mykiss) Redds in the South Fork Tolt River, King County, Washington
}

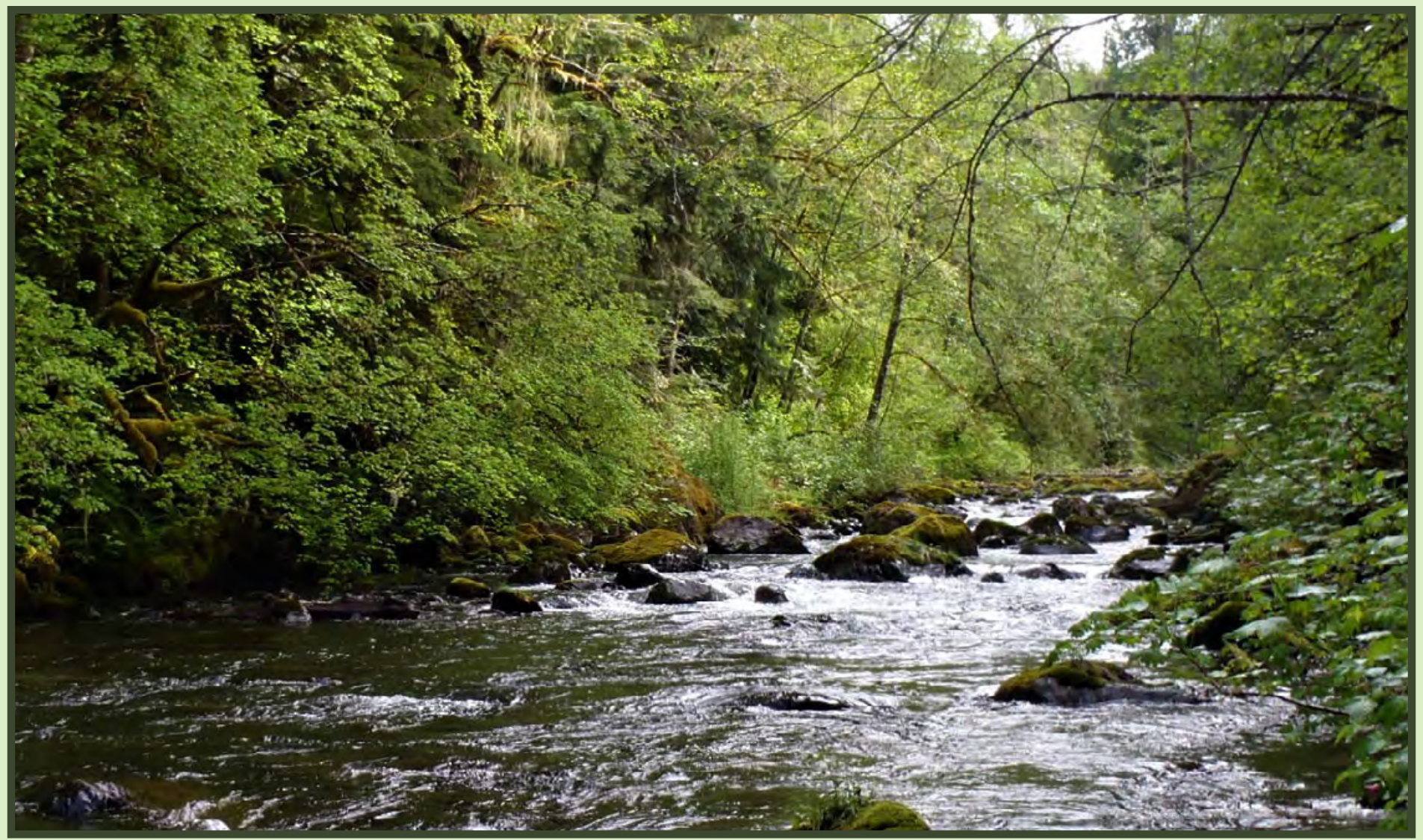

Scientific Investigations Report 2020-5044 
Cover: South Fork Tolt River in King County, Washington, as seen looking upstream from near U.S. Geological Survey streamgage 12148000. (Photograph taken by Andrew S. Gendaszek, U.S. Geological Survey, June 10, 2013.) 


\section{Streambed Scour of Salmon (Oncorhynchus spp.) and Steelhead (Oncorhynchus mykiss) Redds in the South Fork Tolt River, King County, Washington}

By Andrew S. Gendaszek, Elizabeth Ablow, and Derek Marks

Prepared in cooperation with Seattle City Light and Seattle Public Utilities

Scientific Investigations Report 2020-5044 


\title{
U.S. Department of the Interior DAVID L. BERNHARDT \\ U.S. Geological Survey James F. Reilly II, Director
}

\author{
U.S. Geological Survey, Reston, Virginia: 2020
}

For more information on the USGS - the Federal source for science about the Earth, its natural and living resources, natural hazards, and the environment—visit https://www.usgs.gov or call 1-888-ASK-USGS.

For an overview of USGS information products, including maps, imagery, and publications, visit https://store.usgs.gov/.

Any use of trade, firm, or product names is for descriptive purposes only and does not imply endorsement by the U.S. Government.

Although this information product, for the most part, is in the public domain, it also may contain copyrighted materials as noted in the text. Permission to reproduce copyrighted items must be secured from the copyright owner.

Suggested citation:

Gendaszek, A.S., Ablow, E., and Marks, D., 2020, Streambed scour of salmon (Oncorhynchus spp.) and steelhead (Oncorhynchus mykiss) redds in the South Fork Tolt River, King County, Washington: U.S. Geological Survey Scientific Investigations Report 2020-5044, 20 p., https://doi.org/10.3133/sir20205044.

ISSN 2328-0328 (online) 


\section{Contents}

Abstract

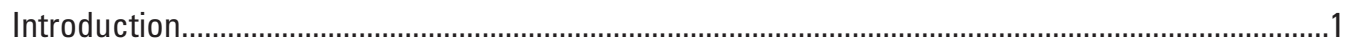

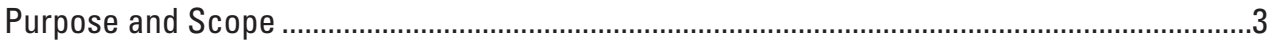

Description of Study Area and Study Reaches ...................................................................

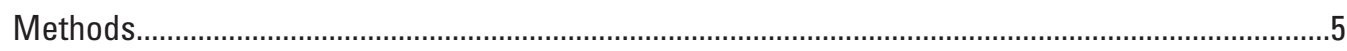

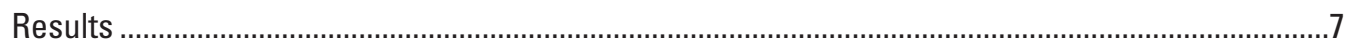

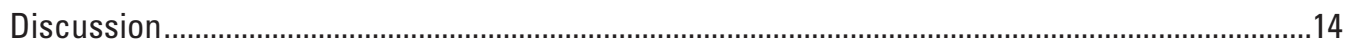

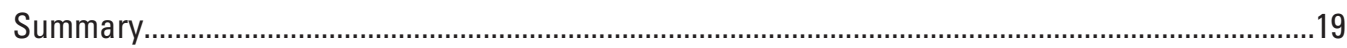

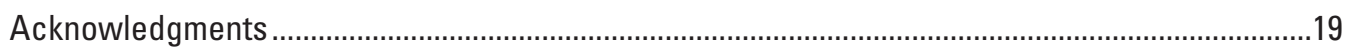

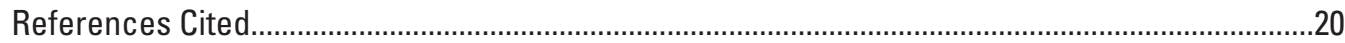

\section{Figures}

1. Map showing locations of study reaches in the South Fork Tolt River, King County, Washington .2

2. Schematic of hydrography and infrastructure of South Fork Tolt River, King County, Washington .4

3. Schematic of accelerometer scour monitor deployment. ..................................................

4. Graphs showing discharge at U.S. Geological Survey streamgages 12148000 and 12148300, South Fork Tolt River, King County, Washington, water year 2016............12

5. Graphs showing discharge measured at USGS streamgages 12148000 , 12148300 minus river return valve, and 12148300 during February 2016 high-flow event and the timing of initial movement and final stability for accelerometer scour monitors recording scour during a February 2016 high-flow event, South Fork Tolt River, King County, Washington

6. Graph showing discharge at U.S. Geological Survey streamgages 12148000 and 12148300, South Fork Tolt River, King County, Washington, water year 2017

7. Maps showing distribution of accelerometer scour monitors deployed in Water Year 2016 and Water Year 2017 in reaches A-D, South Fork Tolt River, King County, Washington, water years 2016 and 2017

\section{Tables}

1. Temporal record of scour recorded and geomorphic data for accelerometer scour monitors deployed during water year 2016.

2. Temporal record of scour recorded and geomorphic data for accelerometer scour monitors deployed during water year 2017 


\section{Conversion Factors}

U.S. customary units to International System of Units

\begin{tabular}{|c|c|c|}
\hline Multiply & By & To obtain \\
\hline \multicolumn{3}{|c|}{ Length } \\
\hline inch (in.) & 2.54 & centimeter $(\mathrm{cm})$ \\
\hline foot (ft) & 0.3048 & meter $(\mathrm{m})$ \\
\hline mile (mi) & 1.609 & kilometer (km) \\
\hline \multicolumn{3}{|c|}{ Area } \\
\hline acre & 0.004047 & square kilometer $\left(\mathrm{km}^{2}\right)$ \\
\hline square mile $\left(\mathrm{mi}^{2}\right)$ & 2.590 & square kilometer $\left(\mathrm{km}^{2}\right)$ \\
\hline \multicolumn{3}{|c|}{ Volume } \\
\hline acre-foot (acre-ft) & 1,233 & cubic meter $\left(\mathrm{m}^{3}\right)$ \\
\hline \multicolumn{3}{|c|}{ Flow rate } \\
\hline cubic foot per second $\left(\mathrm{ft}^{3} / \mathrm{s}\right)$ & 0.02832 & cubic meter per second $\left(\mathrm{m}^{3} / \mathrm{s}\right)$ \\
\hline
\end{tabular}

Temperature in degrees Celsius $\left({ }^{\circ} \mathrm{C}\right)$ may be converted to degrees Fahrenheit $\left({ }^{\circ} \mathrm{F}\right)$ as follows:

$$
{ }^{\circ} \mathrm{F}=\left(1.8 \times{ }^{\circ} \mathrm{C}\right)+32
$$

Temperature in degrees Fahrenheit $\left({ }^{\circ} \mathrm{F}\right)$ may be converted to degrees Celsius $\left({ }^{\circ} \mathrm{C}\right)$ as follows:

$$
{ }^{\circ} \mathrm{C}=\left({ }^{\circ} \mathrm{F}-32\right) / 1.8
$$

\section{Datums}

Vertical coordinate information is referenced to the North American Vertical Datum of 1988 (NAVD 88).

Horizontal coordinate information is referenced to the North American Datum of 1983 (NAD 83).

Elevation, as used in this report, refers to distance above the vertical datum.

\section{Abbreviations}

ASM accelerometer scour monitors

ESA Endangered Species Act

SCL Seattle City Light

SPU Seattle Public Utilities

USGS U.S. Geological Survey

WY water year 


\title{
Streambed Scour of Salmon (Oncorhynchus spp.) and Steelhead (Oncorhynchus mykiss) Redds in the South Fork Tolt River, King County, Washington
}

\author{
By Andrew S. Gendaszek, Elizabeth Ablow, and Derek Marks
}

\section{Abstract}

Prior to emergence as fry, salmonid embryos incubating within gravel nests called "redds" are vulnerable to substrate mobilization and lowering of the streambed, a process termed "streambed scour," during floods. Water managers regulating discharge in salmonid-bearing rivers need information about the magnitude of discharge during which the scour of substrate surrounding salmonid redds occurs. The time when scour occurs, however, is difficult to measure and usually poorly constrained. The South Fork Tolt River in western Washington supplies the City of Seattle with hydroelectric power and about 40 percent of its municipal water needs, while providing spawning habitat for two salmonid species listed under the Endangered Species Act: Chinook salmon (Oncorhynchus tshawytscha) and steelhead trout (O. mykiss). The U.S. Geological Survey, in cooperation with Seattle City Light and Seattle Public Utilities, began a study in 2015 using accelerometer scour monitors (ASM) to characterize the timing of and hydrologic conditions associated with streambed scour at the depth of incubating salmonid embryos in the South Fork Tolt River. Prior to this study, operational thresholds for peak discharge on the South Fork Tolt River were 350 cubic feet per second (cfs) in the upper part of the river and $550 \mathrm{cfs}$ in the lower part of the river as measured at USGS streamgages 12148000 and 12148300 , respectively. These thresholds were developed from the peak discharge associated with observations of the flattening of redd structure and not from direct measurement of scour at the depth of egg pockets within redds. Accelerometer scour monitors were deployed at the level of salmonid egg pockets in spawning habitat of the South Fork Tolt River to record the temporal pattern of streambed scour at the depth of incubating salmon eggs during fall and winter flood seasons of water years (WY) 2016 and 2017. Thirteen of 48 ASMs deployed during the WY 2016 flood season recorded scour attributed to high streamflow when discharge measured at USGS streamgage 12148300 (the lower river streamgage used as an index gage) was between 969 and 1,360 cfs. Local discharge at individual scour sites varied depending on the timing of tributary inputs and downstream transport of water. During the subsequent flood season in
WY 2017, peak discharge at the index gage reached $809 \mathrm{cfs}$. None of the 38 ASMs deployed recorded scour attributed to streamflow alone, although 10 ASMs recorded localized bed movement attributed to spawning activity of fish. Most scour at the depth of redds measured during WY 2016 occurred at or before peak flood discharge consistent with previous redd scour studies. The lack of scour measured in WY 2017 when peak discharge (809 cfs) was less than the minimum discharge when scour occurred in WY 2016 (969 cfs) suggests minimal to no scour of egg pockets in salmonid redds when discharge is less than 809 cfs.

\section{Introduction}

Mobilization of fluvial sediment during floods and consequent lowering of the streambed, a process termed streambed scour, presents a risk to the viability of salmonid embryos incubating in gravel nests called redds. Scour that reaches the depth of egg pockets may entrain or crush developing salmonid embryos resulting in their mortality prior to their emergence as fry from the streambed. In rainfall dominated rivers of western Washington, the incubation period of anadromous salmonids like Chinook salmon (Oncorhynchus tshawytscha) and steelhead trout (O. mykiss) coincides with the fall and winter flood season when sediment-mobilizing discharges most frequently occur. Negative correlation between egg-tofry survival and peak discharge magnitude during incubation in similar salmonid-bearing streams suggests that scour may limit freshwater survival rates of salmonids (Thorne and Ames, 1987). In rivers with natural discharge regimes, salmonids have adapted their spawning behaviors to minimize the risk of scour during floods by constructing their redds in locations unlikely to scour (May and others, 2009) or beneath the depth of typical streambed scour (Montgomery and others, 1996). In regulated rivers with salmonid populations, managers may control, at least in part, the magnitude and duration of peak discharges and thus need information about how management of hydrologic conditions may affect redd scour (Gendaszek and others, 2018). 
The City of Seattle operates a dam on the South Fork Tolt River, which drains part of the western slopes of the Cascade Range and Puget Lowland, for municipal water supply and hydroelectric power generation (fig. 1). The South Fork Tolt River supports native salmonids including fall-run Chinook salmon and summer-run and winter-run steelhead trout that are listed as threatened under the Federal Endangered Species Act (ESA). Therefore, water-resource managers closely control peak-flow dam operations during the 2-3-month period when developing embryos are immobile in river gravels prior to emergence as fry. To mitigate the potential for redd scour, water releases from the South Fork Tolt Dam have been limited, when possible, to meet an operational threshold of maintaining peak flows below $350 \mathrm{cfs}$ as measured at USGS streamgage 12148000 and below $550 \mathrm{cfs}$ as measured at USGS streamgage 12148300. These operational thresholds were developed from the discharges associated with observations of the grading of redd structures including the pit and tailspill to the level of the adjacent unspawned streambed. Developing embryos are contained in pockets of the redd at a lower level of the streambed than the tailspill, which was observed to flatten; consequently, a direct measure of when scour occurs at the level of the redd pit is necessary to determine the discharge when scour impacts developing salmon embryos. The construction and architecture of salmonid redds is described by Burner (1951) in detail. Water managers base operational decisions on discharge, which does not directly control redd scour but does interact with channel morphology and sediment supply to create the hydraulic conditions under which sediment mobilizes and redd scour initiates. The mobilization and downstream transport of sediment must also be greater than upstream sediment supply for the lowering of the streambed to occur. Consequently, the discharge at which scour occurs varies greatly between rivers, within rivers, and even within individual reaches reflecting the stochastic nature of sediment transport. Nevertheless, observations of the time and discharge when scour initiates at the depth of developing salmonid embryos allow water managers to develop protocols to mitigate the impact of scour on egg-to-fry survival that can impact salmonid populations.

Traditional scour monitoring techniques such as scour chains (Emmett and Leopold, 1965) record the location and depth of scour between their deployment and retrieval. The time when scour occurs between deployment and retrieval, however, is not recorded by scour chains and thus multiple high-flow events may occur between scour chain deployment and retrieval or scour may occur at a discharge much less than the peak discharge. The depth of scour recorded by scour

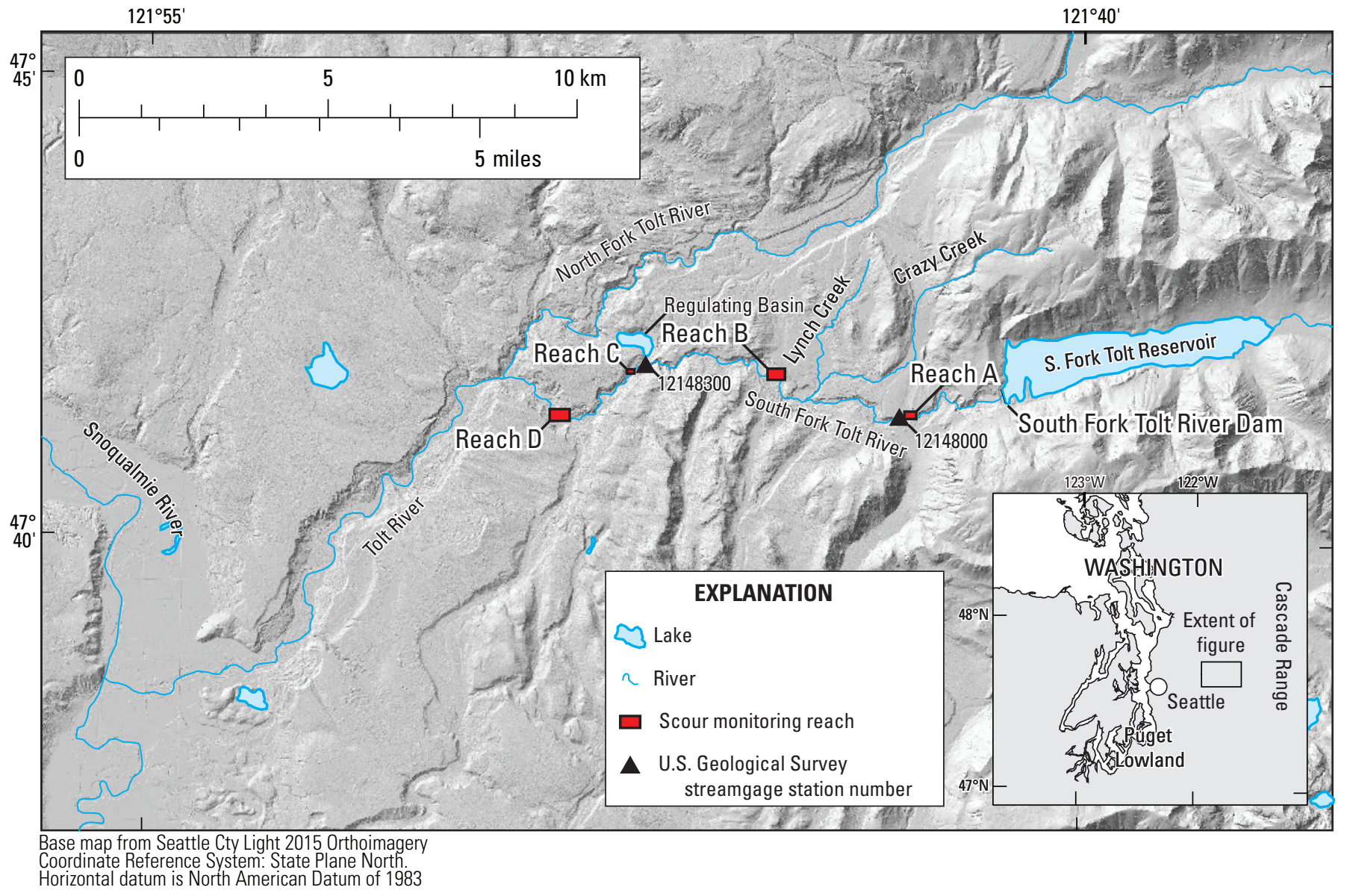

Figure 1. Locations of study reaches in the South Fork Tolt River, King County, Washington. [km, kilometers] 
chains may therefore integrate multiple floods and the hydrologic conditions when scour reaches the depth of egg pockets within redds remain unknown. To address this limitation and determine the time when redd scour initiates in the South Fork Tolt River, we deployed accelerometer scour monitors consisting of data-logging accelerometers (Gendaszek and others, 2013) in documented salmon spawning habitat in water year ${ }^{1}$ (WY) 2016 and WY 2017. We related the time when scour initiated to discharge measured at an index streamgage (USGS streamgage 12148300) to determine the hydrologic conditions when scour occurred. Supporting geomorphic data, including the change in streambed surface between the deployment and retrieval of accelerometer scour monitors and particle-size distributions were collected to provide context for streambed scour measurements.

\section{Purpose and Scope}

The purpose of this report is to inform peak-flow management strategies for the South Fork Tolt River that will reduce the frequency of hydrologic conditions that cause scour of salmonid redds. Information about the timing of streambed scour of Chinook salmon and steelhead redds in the South Fork Tolt River is analyzed in the context of channel geomorphic conditions and hydrologic conditions measured at nearby streamgages during WY 2016 and WY 2017.

\section{Description of Study Area and Study Reaches}

The South Fork Tolt River drains a 31.8-square-mile area of the Cascade Range and Puget Lowland before joining the North Fork Tolt River to form the mainstem Tolt River, a tributary of the Snoqualmie River (fig. 1). Elevation of the South Fork Tolt River watershed ranges from 360 feet (ft) at the confluence of the South and North Forks of the Tolt River to a maximum of $5,460 \mathrm{ft}$ in its headwaters. Most precipitation falls during the fall and winter months as rain and snow at higher elevations with an annual mean of 115 inches for the South Fork Tolt River watershed (1981-2015; PRISM Climate Group, 2014). Atmospheric rivers, which convey large volumes of moisture from the tropical Pacific Ocean, can result in heavy and prolonged precipitation that can lead to flooding in the South Fork Tolt River and western Washington more generally (Neiman and others, 2011).

The South Fork Tolt River is impounded by the South Fork Tolt Dam, which was constructed in 1963 to create the South Fork Tolt Reservoir. This reservoir has a storage capacity of 56,160 acre-ft and supplies 40 percent of Seattle's municipal water. The crest of the dam is at an elevation of $1,775 \mathrm{ft}$, and normal pool levels range from 1,725 to 1,765 $\mathrm{ft}$. Intakes at multiple depths within the reservoir regulate discharge to the South Fork Tolt River downstream of the

\footnotetext{
1A water year is defined as the 12-month period beginning October 1 through September 30 and is designated by the calendar year in which it ends.
}

dam and to a 4.8-mile pipeline that discharges water into an 880 -acre-ft regulating basin before it is treated and delivered to Seattle by pipeline. In 1996, a penstock that parallels the water pipeline and connects to a 16.8-megawatt hydroelectric facility was constructed, diverting additional water from the reservoir. Water discharged from the powerhouse empties into a tailrace that directs water to the regulating basin or to the South Fork Tolt River upstream of USGS streamgage 12148300 via a valve referred to as the "river return valve" (fig. 2).

Although the South Fork Tolt Dam is operated primarily for water supply, it provides for limited peak-flow management of the Tolt and Snoqualmie Rivers. During the fall and winter rainy season, flood storage is maintained to minimize the occurrence of unregulated discharge through the morning glory spillway to the South Fork Tolt River, which occurs when the reservoir water level exceeds the spillway crest at an elevation of 1,762 ft. The morning glory spillway allows water above a certain elevation to pass the dam through a large pipe rather than over the crest of the dam itself. In the spring and the summer, the ring gate of the morning glory spillway is raised to $1,765 \mathrm{ft}$ increasing the dry-season storage capacity of the reservoir.

The City of Seattle owns 70 percent of the watershed draining into the South Fork Tolt Reservoir and manages it as a protected watershed. The remainder of the watershed is owned/managed by the United States Forest Service. Downstream of the South Fork Tolt Dam, the South Fork Tolt watershed is mostly privately owned and managed as industrial timberland. Mixed fir-hemlock coniferous forests predominate in the uplands of the South Fork Tolt River watershed with deciduous trees occurring in riparian areas. Extensive logging throughout the basin since the early 20th century has removed most of the old-growth forest within the South Fork Tolt River watershed and most forest is mature second- or plantation-style third growth.

After establishing its present drainage pattern following recession of Pleistocene glaciers, the South Fork Tolt River incised into bedrock and overlying unconsolidated glacial and non-glacial sedimentary deposits. Bedrock is comprised of Tertiary volcanic rocks, including andesite and basalt, and associated sedimentary rocks (Dragovich and others, 2012). Erosion-resistant bedrock forms steep valley walls that confine sections of the South Fork Tolt River and contribute to high gradients in several sections of the river. Waterfalls and rapids within these high-gradient reaches, including the canyonwaterfall section of the South Fork Tolt River immediately upstream of U.S. Geological Survey streamgage 12148300, become seasonal barriers to anadromous fish migration. Hydraulic conditions render these rapids impassible to winterrun steelhead and salmon during their upstream migration in the winter before spawning shortly thereafter. Summer-run steelhead, however, can swim upstream through these rapids during favorable hydraulic conditions that occur during their unique upstream migration timing in the spring and summer before spawning in the late winter or early spring of the 


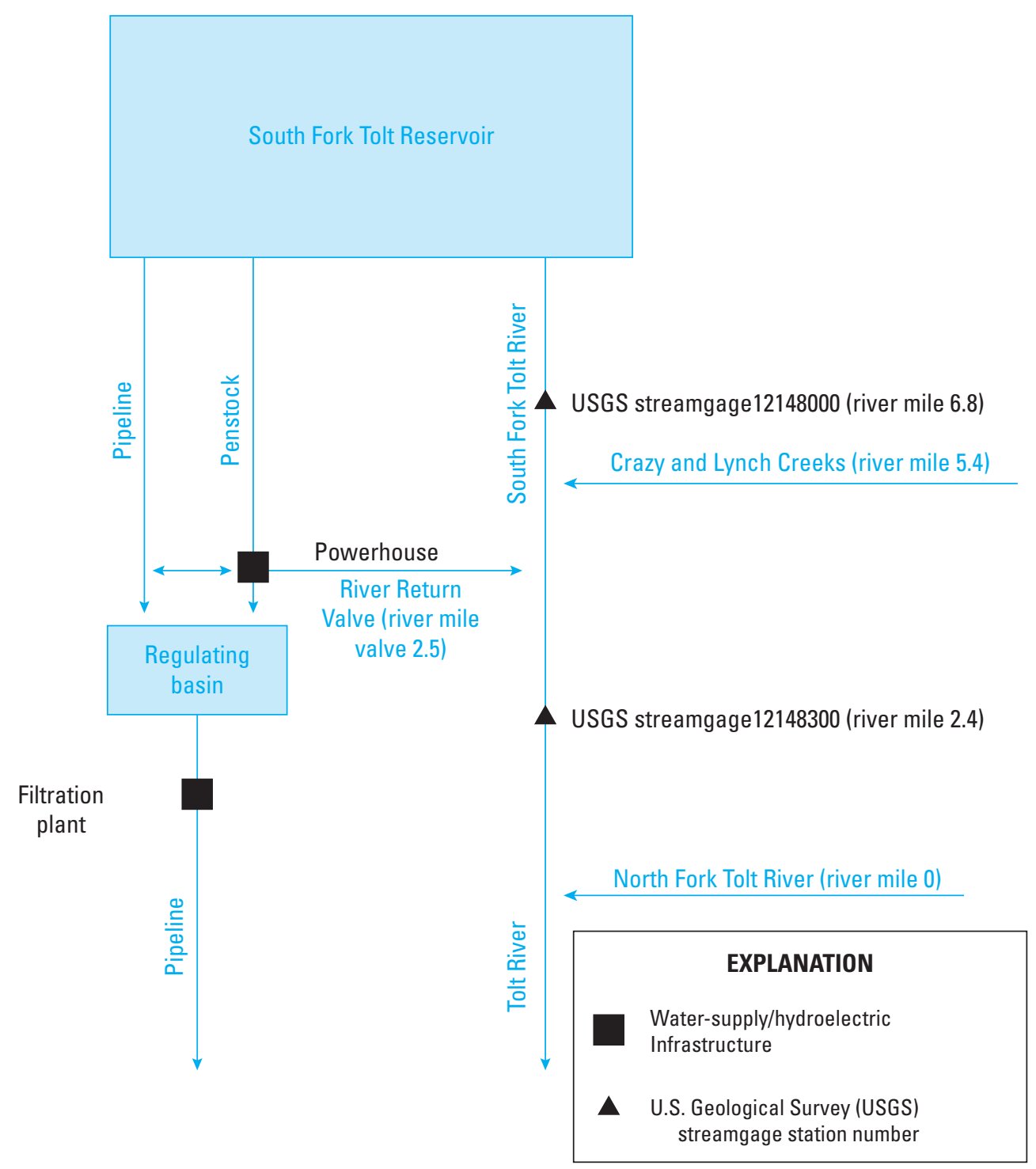

Figure 2. Hydrography and infrastructure of South Fork Tolt River, King County, Washington. [River miles are referenced to the confluence of the North Fork and South Fork Tolt Rivers.]

following year. As a result, summer-run steelhead can spawn at the furthest upstream extent of anadromy at a waterfall approximately 0.3 mile downstream of the South Fork Tolt Dam. Landslides, which predominantly originate in unconsolidated glacial materials and to a lesser degree in bedrock, have been mapped throughout the South Fork Tolt River's valley (Dragovich and others, 2012) and contribute sediment to its channel including boulders that are too large to be moved by the present flow regime. These boulders, however, influence local hydraulics and the scour and deposition of finer-grained sediment in the surrounding channel. River sediment is comprised of locally derived volcanic, sedimentary, and metamorphic rocks as well as eroded unconsolidated glacial sediments.

Four study reaches, referred to alphabetically in the downstream direction, were selected to deploy accelerometer scour monitors including two reaches above the canyon
(Reaches A and B) where summer steelhead spawn and two reaches below the canyon (Reaches $\mathrm{C}$ and $\mathrm{D}$; fig. 1) where winter steelhead and salmon spawn. The most upstream reach (Reach A) was located at and immediately upstream of the USGS streamgage 12148000, which is representative of hydrologic conditions within this reach. Discharge in Reach $\mathrm{A}$ is predominantly regulated by outflow from the South Fork Tolt Dam with some contribution from riparian springs and seeps. Water is conveyed through a single channel in this reach with small, unvegetated islands emergent at low discharge. The upstream part of Reach A is characterized by gravel-to-cobble sized sediment suitable for spawning across much of the channel whereas boulders restrict the occurrence of suitable spawning sediment in the downstream part of Reach A to small, isolated areas that typically occur on the downstream side of boulders. Reach B is located immediately 
downstream from two unregulated tributaries, Lynch and Crazy Creeks. These creeks are not gaged and discharge contributions from them are minor relative to the South Fork Tolt River. Discharge in Reach B includes that measured at USGS streamgage 12148300 minus flow from a river return valve that discharges into the river immediately upstream of USGS streamgage 12148300 . This reach is characterized by a large, vegetated island that splits the South Fork Tolt River into two channels with a larger floodplain through which the channel has historically migrated and avulsed. As a result, discharge at the location of the ASMs, where the flow was split, was a fraction of the discharge recorded at USGS streamgage 12148300 minus flow from a river return valve, but this fraction was not quantified. Gravels suitable for spawning in Reach B typically occurred in isolated patches on the downstream side of large boulders but were distributed across the width of the channel in parts of the side channel devoid of boulders. Downstream of the canyon and at USGS streamgage 12148300 , reach C is near the upstream limit of winter steelhead and salmon spawning. Discharge at this gage is represented by USGS streamgage 12148300, which includes the contributions of Lynch and Crazy Creeks and the river return valve. The river return valve is used to discharge water back to the South Fork Tolt River that is not needed for water supply but has been used for power generation. Numerous boulders deposited in Reach C limited the extent of spawning gravels to localized patches downstream of boulders. Reach D is downstream of reach $\mathrm{C}$ and does not include any major surface-water tributaries and is therefore represented by discharge measured at USGS streamgage 12148300 .

\section{Methods}

Accelerometer scour monitors (ASMs; Gendaszek and others, 2013) were deployed in reaches regularly used by Chinook salmon and steelhead for spawning in the South Fork Tolt River to measure the timing of streambed scour at the depth of salmonid embryos developing in redds during WY 2016 and 2017 fall and winter flood season. In the Pacific Northwest, the incubation of most salmonid embryos corresponds to the fall and winter rainy season when the probability of sediment-mobilizing floods is greatest. Forty-eight accelerometer scour monitors were deployed in four reaches of the South Fork Tolt River during WY 2016; 38 accelerometer scour monitors were re-deployed in reaches A and B during WY 2017. For this study, accelerometer naming conventions combined the reach, water year of deployment, and downstream number. For example, the most upstream ASM deployed in reach C during WY 2016 was named C-WY16-01.

The temporal record of streambed scour was measured by ASMs, which recorded their three-dimensional orientation at 15-minute intervals from October 1 after their deployment to May of the following calendar year. This period that included the fall and winter flood season when high discharges were most likely occur. Each ASM was constructed from two Onset Hobo Pendant-G accelerometers (use of trade or brand names in this paper is for identification purposes only and does not constitute endorsement by the U.S. Geological Survey) encased in 6-centimeter $(\mathrm{cm})$ lengths of 4-cm diameter schedule 40 polyvinyl chloride (PVC) tubing, which was similar in diameter to the median particle size of the substrate in which it was deployed (fig. 3). ASMs were also weighted to have a density comparable to streambed sediment (3.0 grams per cubic centimeter $\left[\mathrm{g} / \mathrm{cm}^{3}\right]$ ) so that they did not float. Accelerometers remained in a stable orientation until the surrounding gravel matrix was mobilized as sediment was transported due to streambed scour or the digging of redds. Error associated with the measurement of each axis' tilt ranged from about 5 degrees to 22 degrees at a temperature of $25^{\circ} \mathrm{C}$ as a function of logger orientation and temperature. Passive integrated transponders (PIT) tags were affixed to the uppermost accelerometer of each ASM to aid in their post-flood season recovery. Accelerometers were attached by braided cable to an anchor comprised of an 8-cm piece of angle steel that was installed below the depth of expected streambed scour so that the scour monitors would not be transported downstream during flood events and could therefore be retrieved. Accelerometer scour monitors were inserted into the streambed at specific depths by pounding a $6-\mathrm{cm}$ diameter hole using a hand-driven pounding device like that described by Klassen and Northcote (1986). The depth of accelerometers was determined by the length of the braided cables attaching the accelerometers to the anchor and the depth of the anchor prior to deployment. As the pounding device was removed, the accelerometers were held at a constant level by taut nylon cords as gravel collapsed around the surrounding void. The depth of upper accelerometers was targeted to be $15 \mathrm{~cm}$ below the pre-flood season streambed and the depth of lower accelerometers were targeted to be $35 \mathrm{~cm}$, which represented depths of the top and bottom of typical steelhead egg pockets compiled from a literature review by DeVries (1997). Chinook salmon redd pockets are deeper and range from 15 to $50 \mathrm{~cm}$ (DeVries, 1997). Actual installation depths varied from these target depths because of variation in site conditions. In WY 2016, upper accelerometers were installed to a median depth of $13 \mathrm{~cm}$ (range: 5-23 cm), and lower accelerometers were installed to a median depth of $31 \mathrm{~cm}$ (range: $20-53 \mathrm{~cm}$ ). In WY 2017, upper accelerometers were installed to a median depth of $9 \mathrm{~cm}$ (range: $3-15 \mathrm{~cm}$ ) and lower accelerometers were installed to a median depth of $30 \mathrm{~cm}$ (range: 30-31 $\mathrm{cm}$ ). The installation minimized disturbance to the streambed substrate by temporarily compacting the surrounding gravel to create the void into which the accelerometers were inserted.

At each ASM site, particle-size distribution of surface sediment was estimated and the level of the bed surface and location of the ASM was measured relative to local benchmarks. Particle size distribution of the streambed was estimated through Wolman pebble counts (Wolman, 1954) using gravelometers to measure the intermediate diameter of particles. For sites clustered within distinct gravel patches, the results of a single pebble count were applied to all sites within the gravel patch. The vertical level of the streambed of each 


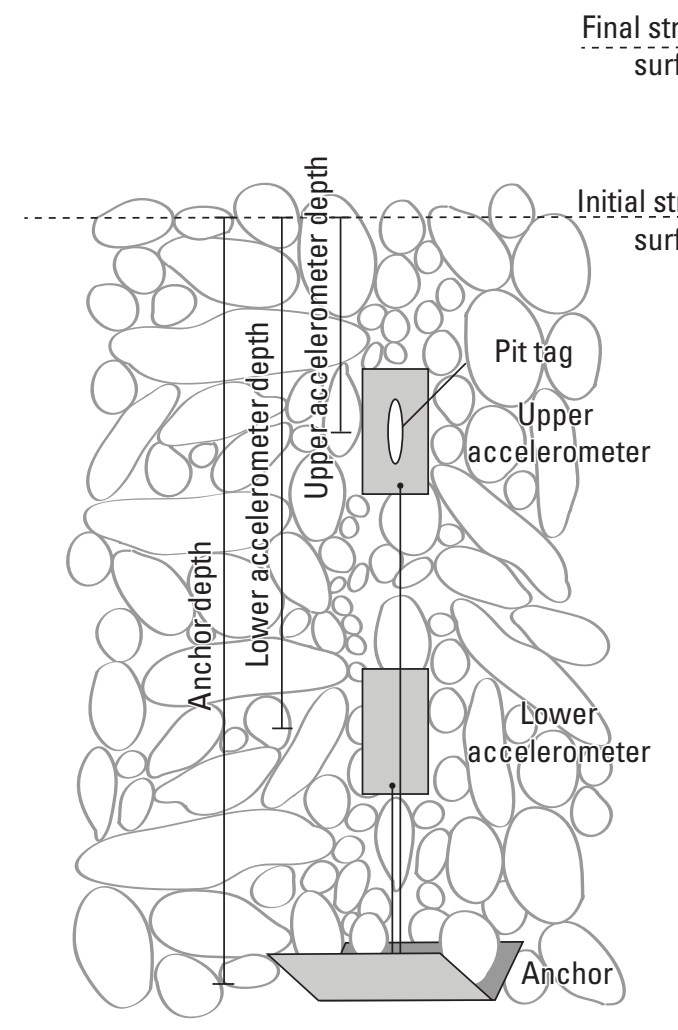

$a$

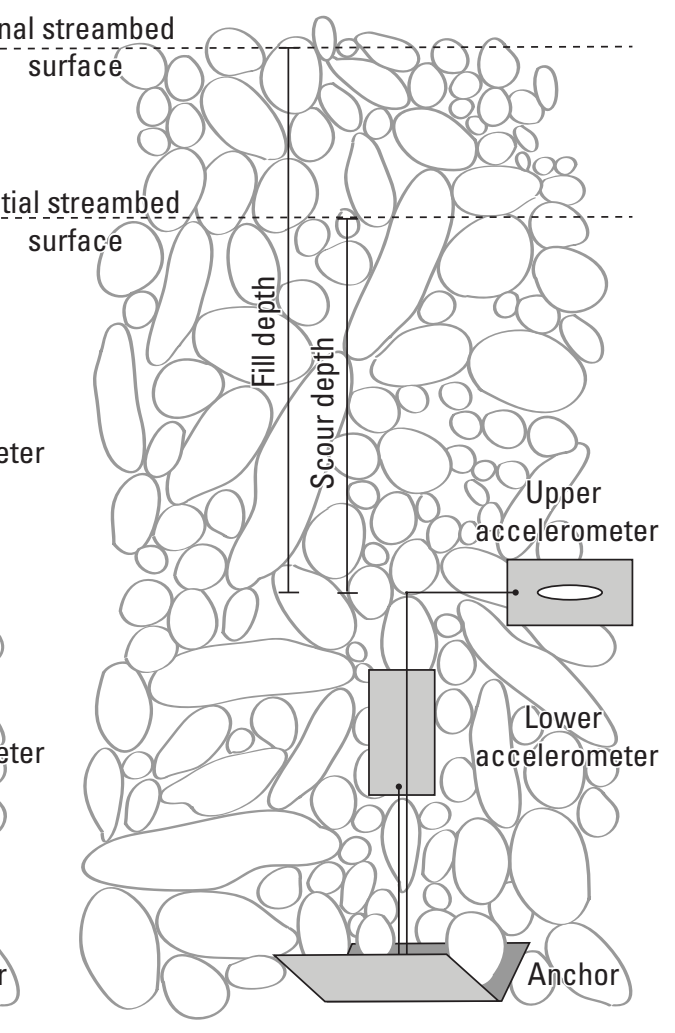

$b$

Figure 3. Accelerometer scour monitor deployment. [A, Initial deployment of two accelerometers connected to an anchor using braided cable; $B$, final orientation of accelerometers after flood season. Passive integrated transponders (PIT) tags were attached to the upper accelerometer to facilitate post-flood season retrieval. Adapted from Gendaszek and others (2013).]

ASM site was surveyed relative to a local network of benchmarks using an automatic level and stadia rod with a vertical accuracy of $0.001 \mathrm{ft}$. The horizontal distance from each ASM site relative to three benchmarks was measured using a measuring tape. After the flood season, ASM sites were located by finding the intersection of three circles surrounding the benchmarks with a radius of the distance recorded before the flood season. In addition, a PIT tag reader, capable of locating PIT tags attached to the uppermost accelerometer of each ASM to within several $\mathrm{ft}$, was also used to facilitate relocation of ASM sites. The post-flood season elevation of the streambed was then surveyed using an automatic level and stadia rod. Net scour during the flood season was calculated as the difference between the pre- and post-flood season bed surface. ASMs were then exhumed using shovels and when the accelerometer was found in an undisturbed position, the level of the accelerometer was measured using a stadia rod. Maximum scour was calculated as the difference between the pre-flood season streambed and the level of the post-flood season accelerometer. In a few cases where the exhumation process disturbed the post-flood season position of the accelerometer, it was assumed that maximum scour reached at least the depth of the initial deployment level. After ASMs were retrieved in the field, timeseries data about each accelerometer's three-dimensional orientation were downloaded, analyzed, and published in ScienceBase (Gendaszek, 2019). When the streambed was observed to be stable, small changes in tilt of less than 15 degrees were recorded by accelerometers; therefore, repeated changes in tilt that exceeded 15 degrees from the initial deployed orientation were inferred to be indicative of accelerometer disturbance (Gendaszek and others, 2013). Accelerometer disturbances were then analyzed in the context of the record of discharge and spawn timing to determine if disturbances were caused by streambed scour during high-flow events or by fish excavating redds during spawning season. Discharge data measured at USGS streamgages were obtained from the National Water Information System (NWIS; U.S. Geological Survey, 2019). 


\section{Results}

Accelerometer scour monitors were located, surveyed, and recovered in July and August during summer baseflow when the channel was wadable. Summaries of the timing of scour, hydrologic conditions recorded during scour, and geomorphic conditions including changes in streambed elevation are presented in table 1 for WY 2016 and table 2 for WY 2017. Forty-seven of the 48 ASMs deployed during WY 2016, and all 38 ASMs deployed during WY 2017 were fully or partially recovered. At some ASM sites, deep burial or high-velocity current prevented retrieval of the lower accelerometer, but upper accelerometers at these sites did not record movement during the flood season and it was assumed that lower accelerometers did not record movement either. At one site, largescale channel changes due to the downstream transport of a piece of large wood occurred near the location of the single ASM that was not recovered (C-WY16-28).

Thirteen of the 48 ASMs deployed during WY 2016 recorded movement during a February 2016 high-flow event when discharge reached $1,400 \mathrm{cfs}$ at USGS streamgage 12148300 (fig. 4), which was the maximum discharge during the ASM deployments. No other movement was recorded by ASMs for the remainder of WY 2016 when discharge was regulated by the South Fork Tolt Dam to not exceed $550 \mathrm{cfs}$ at USGS streamgage 12148300 . Only the upper accelerometers of these 13 ASMs recorded movement whereas the corresponding lower accelerometers remained stable. Discharge for the streamgage most characteristic of hydrologic conditions at each of these sites, referred to as "local discharge," ranged from $821 \mathrm{cfs}$ (ASM A-WY16-3) to 1,360 cfs (ASM B-WY16-11) when ASMs first recorded movement. Discharge measured at the index streamgage (USGS streamgage 12148300) ranged from $969 \mathrm{cfs}$ (ASM B-WY16-01) to 1,360 cfs (ASM B-WY16-11) when ASMs first recorded movement. The initiation of ASM movement, marking the time when scour reached the depth of the upper accelerometer, mostly occurred before the peak of the February 2016 highflow event (fig. 5). Many of these accelerometers recorded intermittent movement during and after the peak of this event indicating that they were freely moving at or above the level of the streambed. These accelerometers remained mobile until sediment was deposited as fill above the accelerometers and movement of the accelerometers ceased. Maximum scour recorded at the 13 ASM locations where scour was recorded ranged from 3 to $19 \mathrm{~cm}$ below the pre-flood season streambed. Scour less than the deployment depths of the upper accelerometers may have occurred but remained undetected by the ASMs. Net streambed elevation changes during the WY 2016 flood season ranged from $19 \mathrm{~cm}$ below the pre-flood season streambed to $23 \mathrm{~cm}$ above the pre-flood season streambed. Median (D50) and 90th percentile (D90) particle size for pre-flood season surface sediment at WY 2016 ASM locations averaged 36 millimeters (mm; range: $11-59 \mathrm{~mm}$ ) and $97 \mathrm{~mm}$ (range: 49-295 mm), respectively.

During WY 2017, two high-flow events exceeded the 550-cfs operational thresholds for scour at USGS streamgage 12148300 (fig. 6). Discharge for the first high-flow event peaked at $798 \mathrm{cfs}$ on March 18, 2017, and discharge for the second high-flow event peaked at $809 \mathrm{cfs}$ on March 30, 2017. Peak discharge for both events did not exceed 969 cfs at USGS streamgage 12148300, the minimum discharge recorded by an ASM in WY 2016 at the time of scour initiation. No ASMs recorded scour during peak-flow events in WY 2017, but the upper accelerometers of 10 ASMs recorded movement during February and March when discharge at USGS streamgage 12148300 ranged from 160 to $314 \mathrm{cfs}$. These movements recorded by ASMs occurred in between peak-flow events and were therefore not attributed to scour from sediment transport during high-flow events. Instead, these movements were attributed to the digging of redds by summer steelhead, which spawn February and March. Median net change in streambed elevation from the beginning to the end of the WY 2017 flood season was negligible at each of the sites but ranged from $13 \mathrm{~cm}$ below the pre-flood season streambed to $9 \mathrm{~cm}$ higher, which may have resulted from the construction of redds. Net lowering of streambed surface was, except for A-WY17-09, less than the depth of the deployed upper accelerometers (table 2). This suggests that some scour due to sediment transport during high-flow events could have occurred during WY 2017, but was less than the depth of upper accelerometers. Median (D50) and 90th percentile (D90) particle size for pre-flood season surface sediment at WY 2017 ASM locations averaged $27 \mathrm{~mm}$ (range: 20-43 mm) and $66 \mathrm{~mm}$ (range: 39-115 $\mathrm{mm}$ ), respectively. 


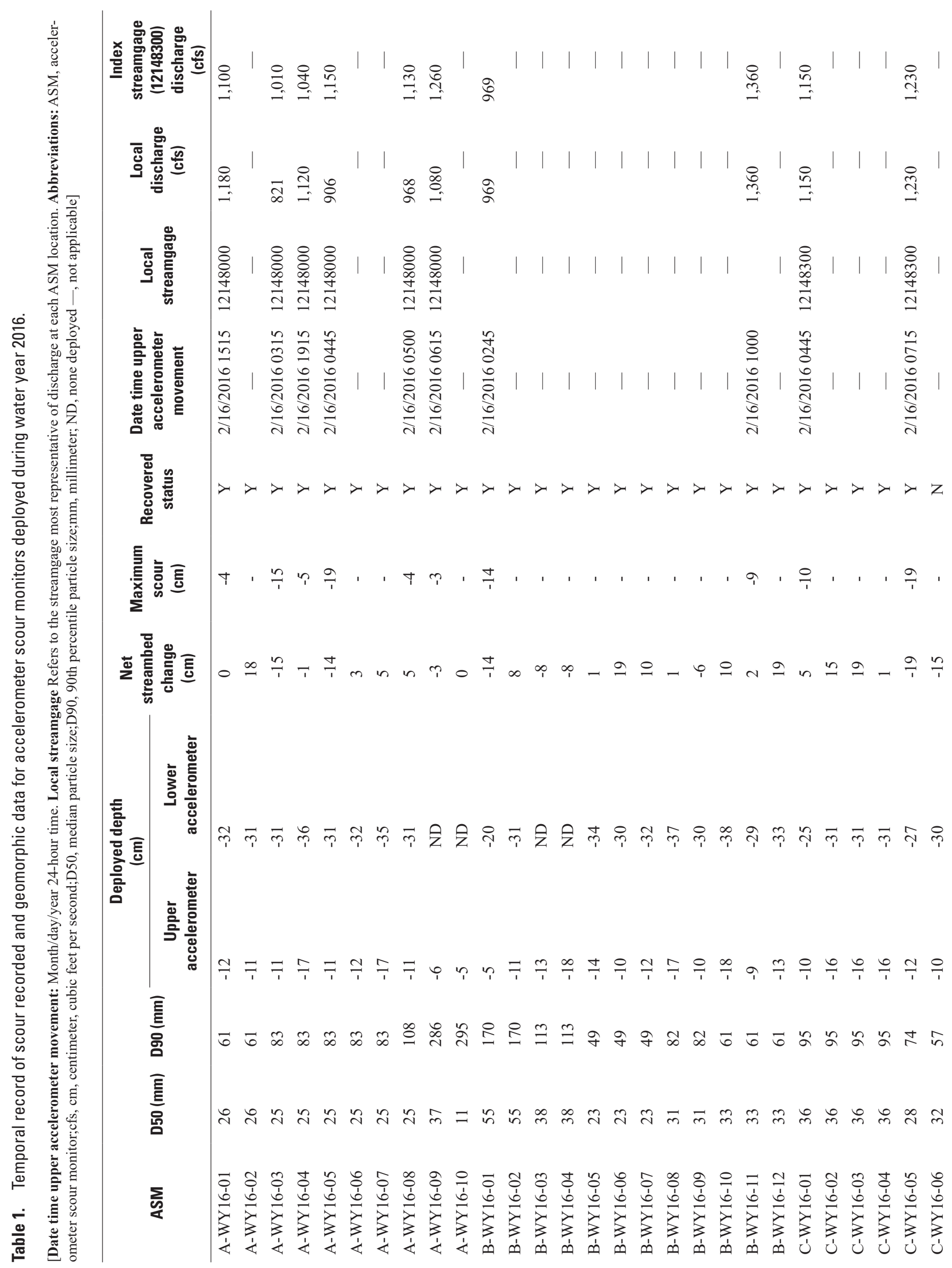




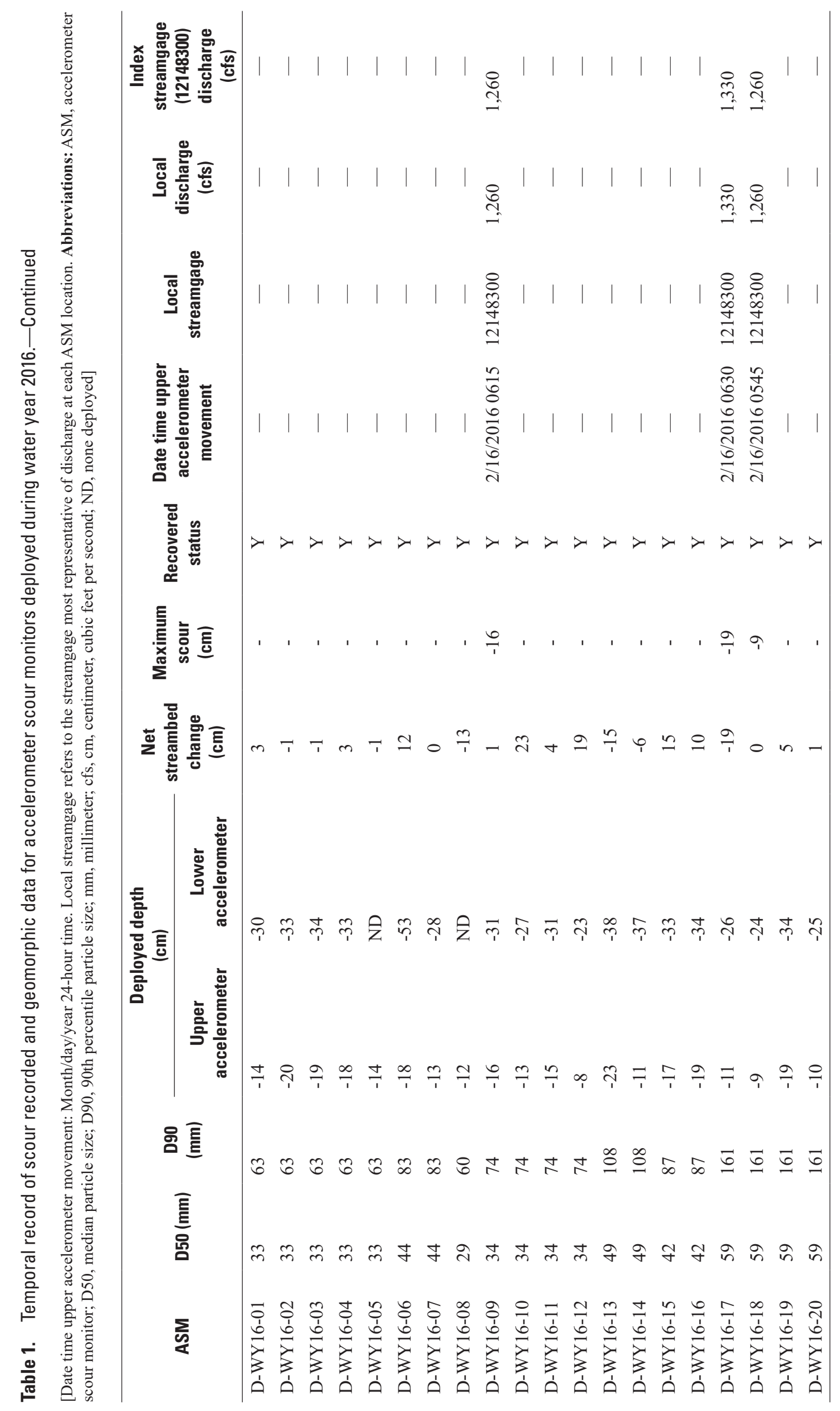




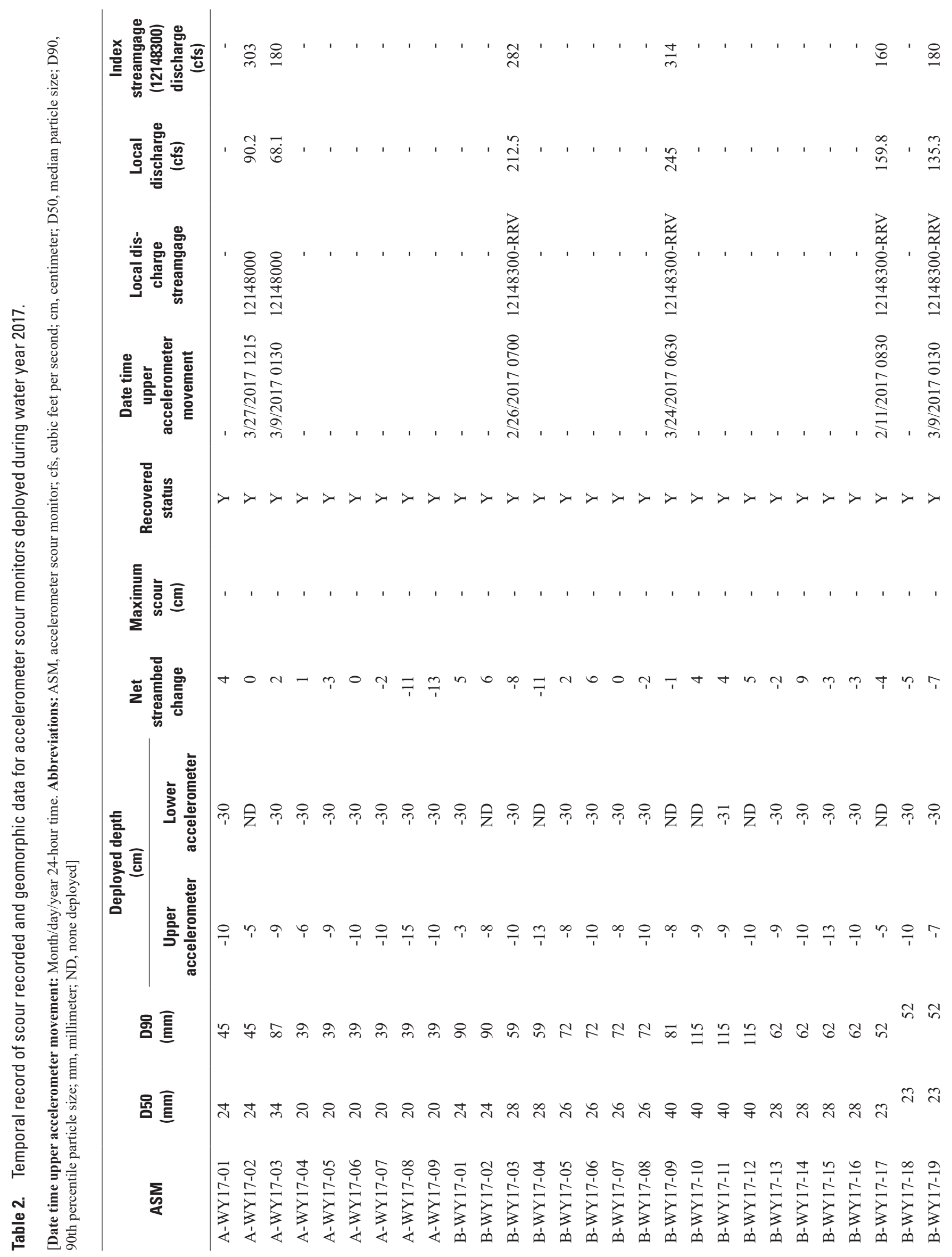




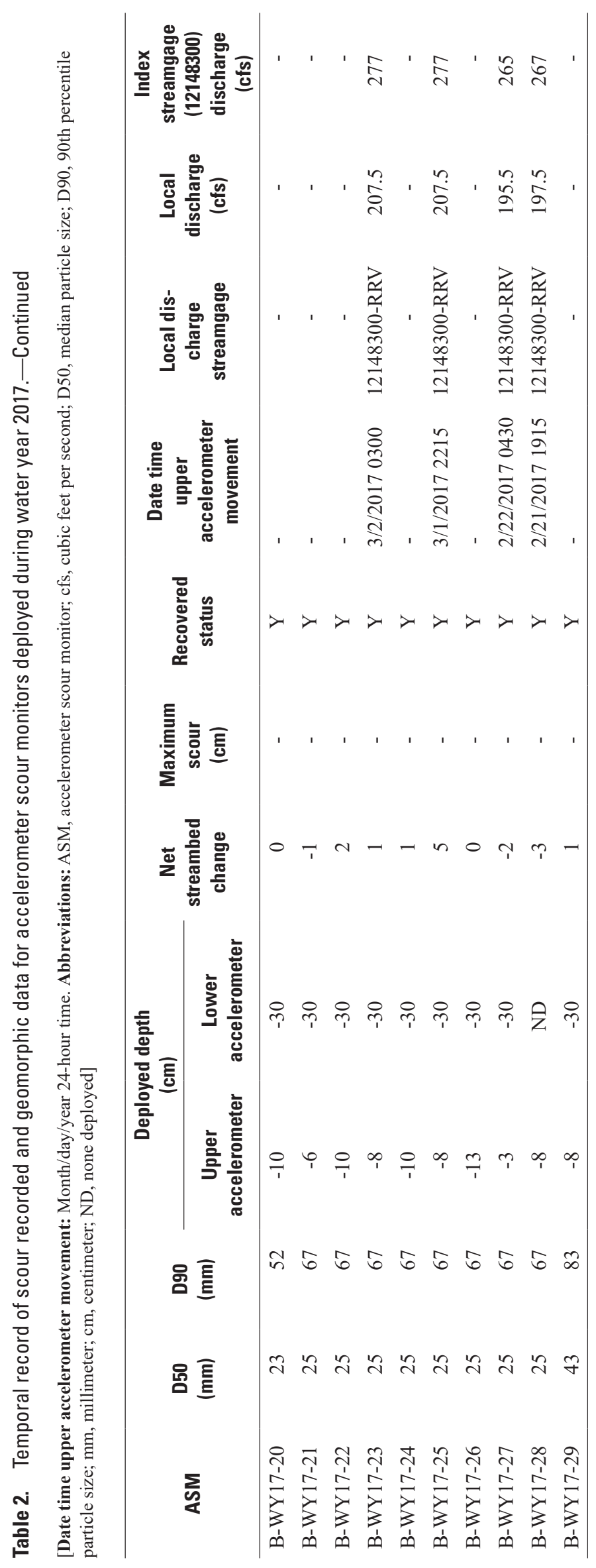




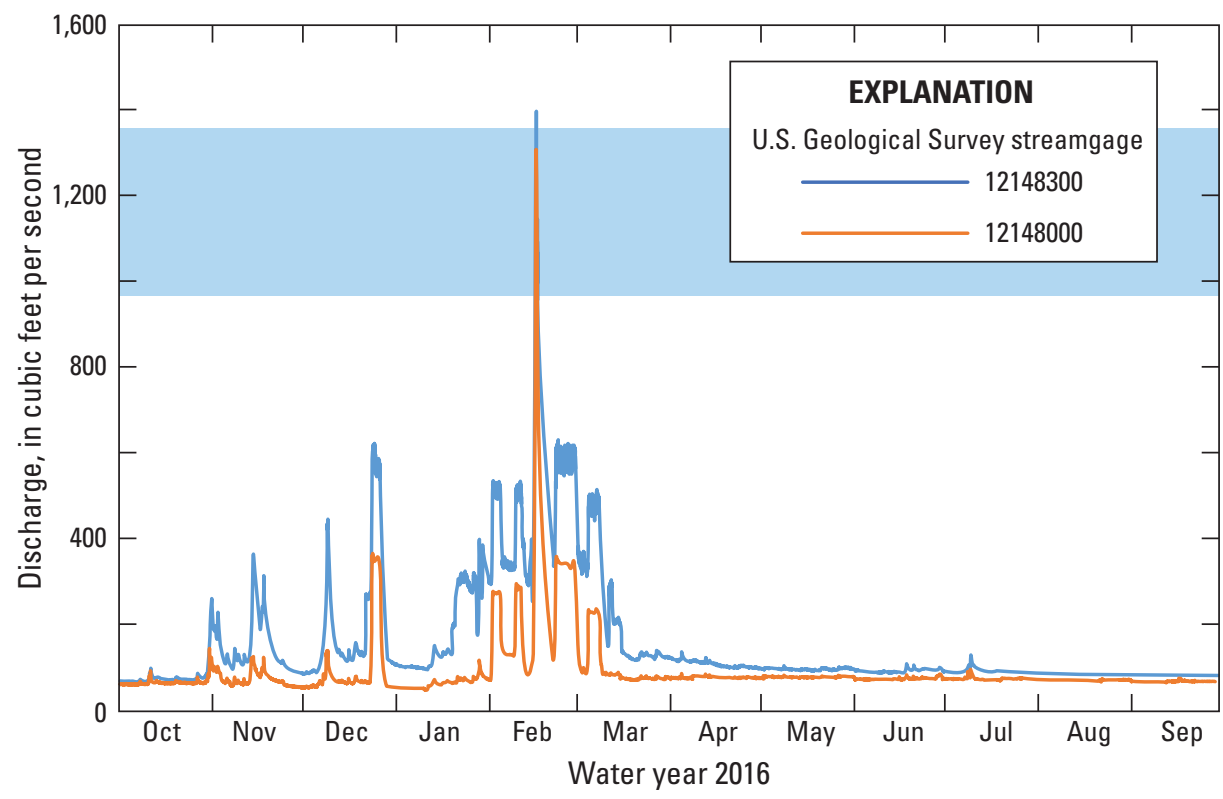

Figure 4. Discharge at U.S. Geological Survey streamgages 12148000 and 12148300 , South Fork Tolt River, King County, Washington, water year 2016. 

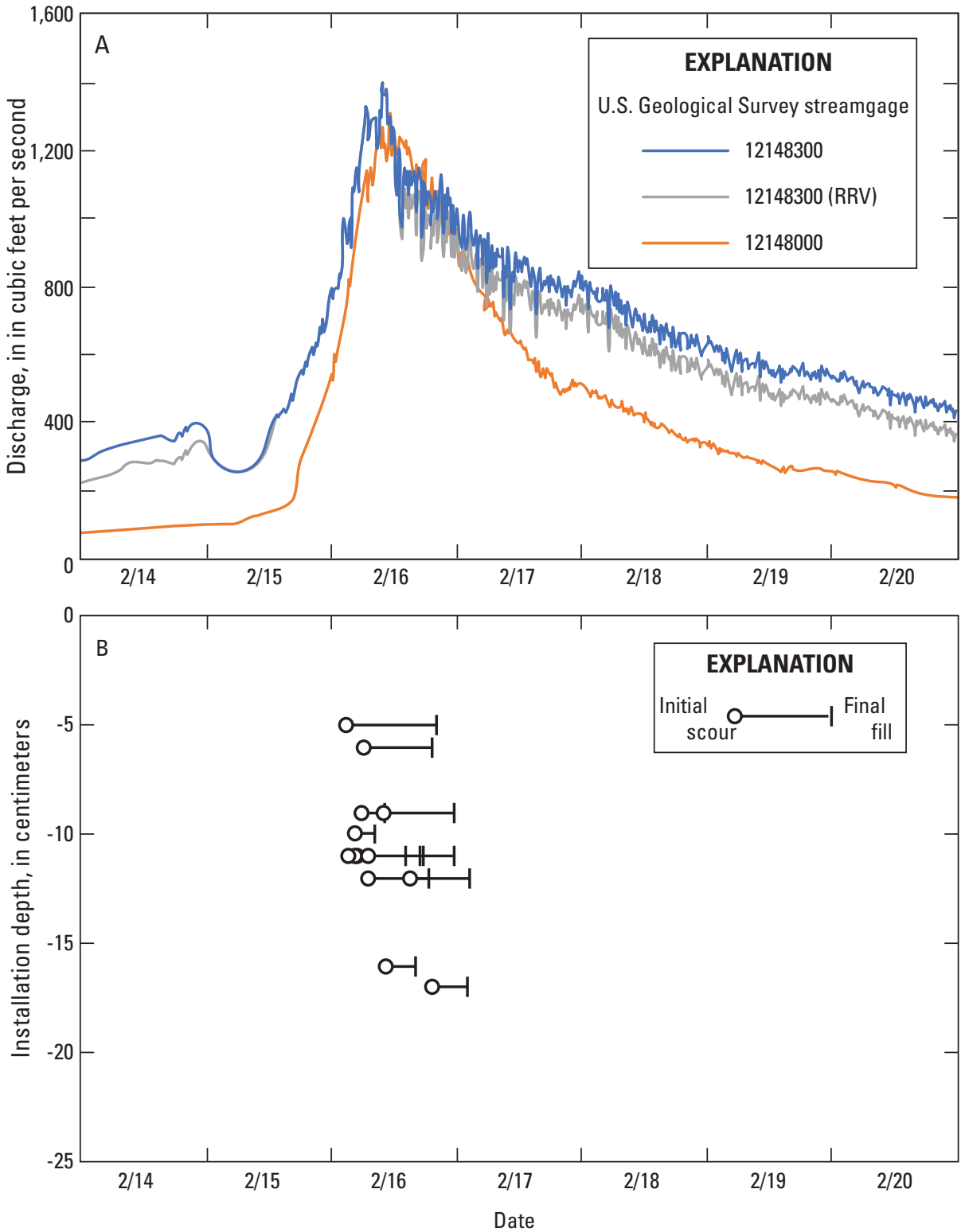

Figure 5. Discharge measured at U.S. Geological Survey streamgages 12148000, 12148300 minus river return valve, and 12148300 during February 2016 high-flow event $(A)$ and the timing of initial movement and final stability for accelerometer scour monitors recording scour during a February 2016 high-flow event (B), South Fork Tolt River, King County, Washington. [A river return valve (RRV) discharges into the river immediately upstream of streamflow-gaging station 12148300 . Discharge at streamgage 12148300 reached 1,400 cubic feet per second at the peak of the February 2016 high-flow event.] 


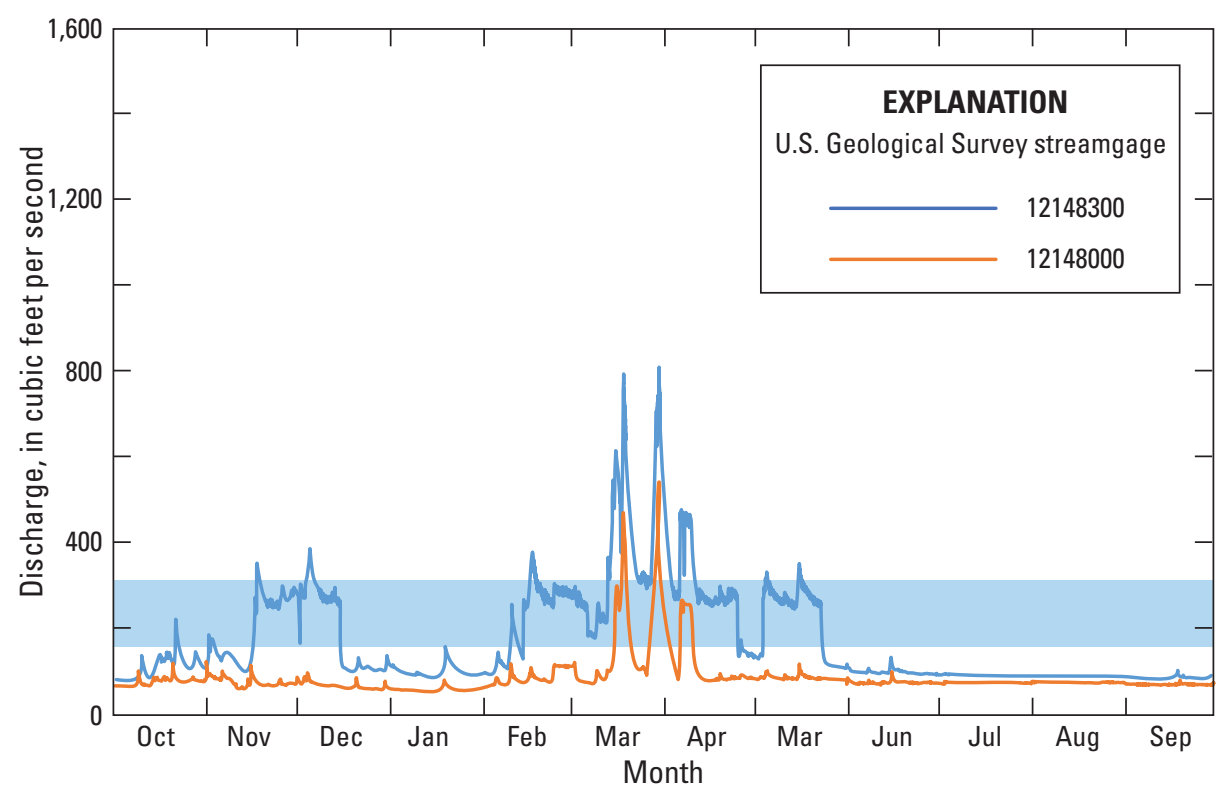

Figure 6. Discharge at U.S. Geological Survey streamgages 12148000 and 12148300 , South Fork Tolt River, King County, Washington, water year 2017. [Blue shading indicates range of discharges measured at 12148300 during which spawning movements occurred.]

\section{Discussion}

Hydrologic conditions and regulation of the South Fork Tolt River differed between WY 2016 and WY 2017, the 2 years of scour monitoring. At the beginning of WY 2016, the South Fork Tolt Reservoir was at a lower-than-normal elevation $(1,715 \mathrm{ft})$ due to an exceptionally low winter snowpack followed by a drier and hotter summer that resulted in low runoff and increased water demand during drought conditions for the previous water year. As a result, the reservoir was able to retain a larger volume of fall and winter runoff than normal before the elevation of the spillway crest was reached and unregulated discharge was released downstream. Consequently, storms that resulted in high-flow events in neighboring unregulated rivers during fall and early winter in WY 2016 did not cause similar increases in the discharge of the South Fork Tolt River. In WY 2016, the only high-flow event that exceeded the operational thresholds peaked at 1,310 and 1,400 cfs on February 16 at the USGS 12148000 and 12148300 streamgages, respectively. During this high-flow event, the South Fork Tolt Reservoir water level exceeded $1,762 \mathrm{ft}$, and unregulated spill from the reservoir discharged into the South Fork Tolt River. At the outset of WY 2017, the level of the South Fork Tolt Reservoir was nearly 1,737 ft, but runoff from fall and winter storms during WY 2017 was less than WY 2016. As a result, a lower volume of runoff was required to fill the reservoir to the elevation of the spillway in WY 2017, but this occurred earlier than in the previous water year. Peak discharge exceeded operational thresholds on two occasions during high-flow events on March 18 and March 30 during WY 2017. Peak discharge magnitude for these events
(798 and 864 cfs, respectively), however, was about 60 percent of the peak discharge magnitude of the February 16, 2016, peak-flow event as measured at USGS streamgage 12148300.

The temporal record of ASM movement revealed streambed scour at 13 of the 48 ASMs (27 percent) deployed in WY 2016 during the February 16 high-flow event but no scour due to sediment transport during other high-flow events during WY 2016 and WY 2017. At these 13 locations, only upper accelerometers originally installed between 5 and $17 \mathrm{~cm}$ below the pre-flood season streambed recorded scour. None of the lower accelerometers installed between 20 and $53 \mathrm{~cm}$ recording scour. Therefore, egg pockets at these depths would have been partially, but not completely, scoured by the February 16 peak-flow event. In-channel boulders, wood, and bedrock created localized areas of streambed scour and deposition. In some cases, patches of gravel used for spawning were as small as of 1 square meter, occurring on the downstream side of obstructions like boulders.

Scour was not evenly distributed across the four ASM deployment reaches. Six of 10 ASMs deployed in reach A recorded scour during the February 16 high-flow event (fig. $7 \mathrm{~A}$ ), whereas the remaining $7 \mathrm{ASMs}$ that recorded scour were among the remaining $38 \mathrm{ASM}$ deployed during WY 2016 within reaches $\mathrm{B}, \mathrm{C}$, and D (figs. 7B-D). Average D50 (median particle size) of surface sediment at ASM sites in reach A was smaller $(25 \mathrm{~mm})$ than in reaches $B(35 \mathrm{~mm})$, C (34 mm), and D (42 mm); however, D90 (90th percentile particle size) was larger in reach $\mathrm{A}(123 \mathrm{~mm})$ than in reaches B (88 mm), C (85 mm), and D (94 mm). The large D90 relative to D50 characteristic of sites in reach A results from fine-grained sediment deposited on the lee side of boulders, 
which form small gravel patches used for spawning by fish. Increased scour measured in reach A suggests that fine-grained sediment in streambed scours more frequently despite the presence of larger boulders. Maximum scour (in other words, the maximum lowering of the streambed) during the flood season recorded by ASMs during WY 2016 was as deep as 19 $\mathrm{cm}$ below the pre-flood season streambed; at some locations net streambed change (in other words, the difference between the level of the pre- and post-flood season streambed) was equivalent to maximum scour (for example, A-WY16-03, B-WY16-01, and C-WY16-05). At these locations, no sediment was deposited as fill after scour occurred and the level of the post-flood season streambed was lower than the pre-flood season streambed suggesting a net loss of sediment from these locations during WY 2016. At all other ASM locations recording scour, sediment was deposited and the streambed was higher than the level of maximum scour recorded by the ASM.

During WY 2016, scour initiated when local discharge ranged from $821 \mathrm{cfs}$ at ASM A-WY16-03 (USGS streamgage 12148000 ) to $1,360 \mathrm{cfs}$ at ASM B-WY16-11 (USGS streamgage 12148300 minus River Return Valve). Discharge at USGS streamgage 12148300, when scour initiated, ranged from 969 to 1,360 cfs. Discharge does not directly determine when and where scour occurs but interacts with physical characteristics of the channel including width, depth, and roughness elements created by sediment, bedforms, and large wood to create the hydraulic conditions under which sediment mobilizes and scour occurs. The depth of scour reflects the balance between the supply of sediment and the rate of its transport, which can vary both temporally and spatially in response to variability in the interaction between hydraulic forces and the streambed. Most recorded scour initiated before the peak of the February 16 high-flow event with only two ASMs recording scour initiation after the peak. This is consistent with previous scour monitoring studies (for example, Gendaszek and others, 2013 and DeVries and others, 2001) that show that most scour occurred at or before the peak discharge event with deposition of sediment following the peak. Although sediment transport was not directly measured, maximum extent of scour prior to peak discharge is consistent with higher sediment transport occurring on the rising limb of the peak-flow hydrograph (clockwise hysteresis of sediment transport) that occurs in sediment-supply limited systems (Whiting and others, 1999). Sediment deposited above the maximum depth of scour was also recorded at most ASM locations that recorded scour suggesting widespread deposition on the falling limb of the peak-flow hydrograph. No major avulsions (that is, sudden displacement of the river channel) occurred during the February 2016 high-flow event and therefore scour recorded by ASMs was attributed to general bed movement and not adjustment to large-scale geomorphic channel changes.

No scour occurred due to sediment transport during the two high-flow events during WY 2017 that exceeded operational thresholds, but 10 ASMs recorded movement during low-flow periods between high-flow events (table 2). These movements occurred between February and March when discharge was stable or decreasing, and coincided with the spawn timing of summer steelhead, as confirmed by Washington Department of Fish and Wildlife spawning survey crews. As a result, these movements were not attributed to scour from sediment transport, but rather to the digging of redds. Similar movements attributed to spawning fish were reported in the Cedar River by Gendaszek and others (2013) and Gendaszek and others (2018) and in Issaquah Creek by DeVries (2001). The lack of scour due to sediment transport in WY 2017 when maximum discharge reached $809 \mathrm{cfs}$ at USGS streamgage 12148300 is consistent with the minimum discharge when scour was observed in WY 2016 (969 cfs). 


\section{Reach A}

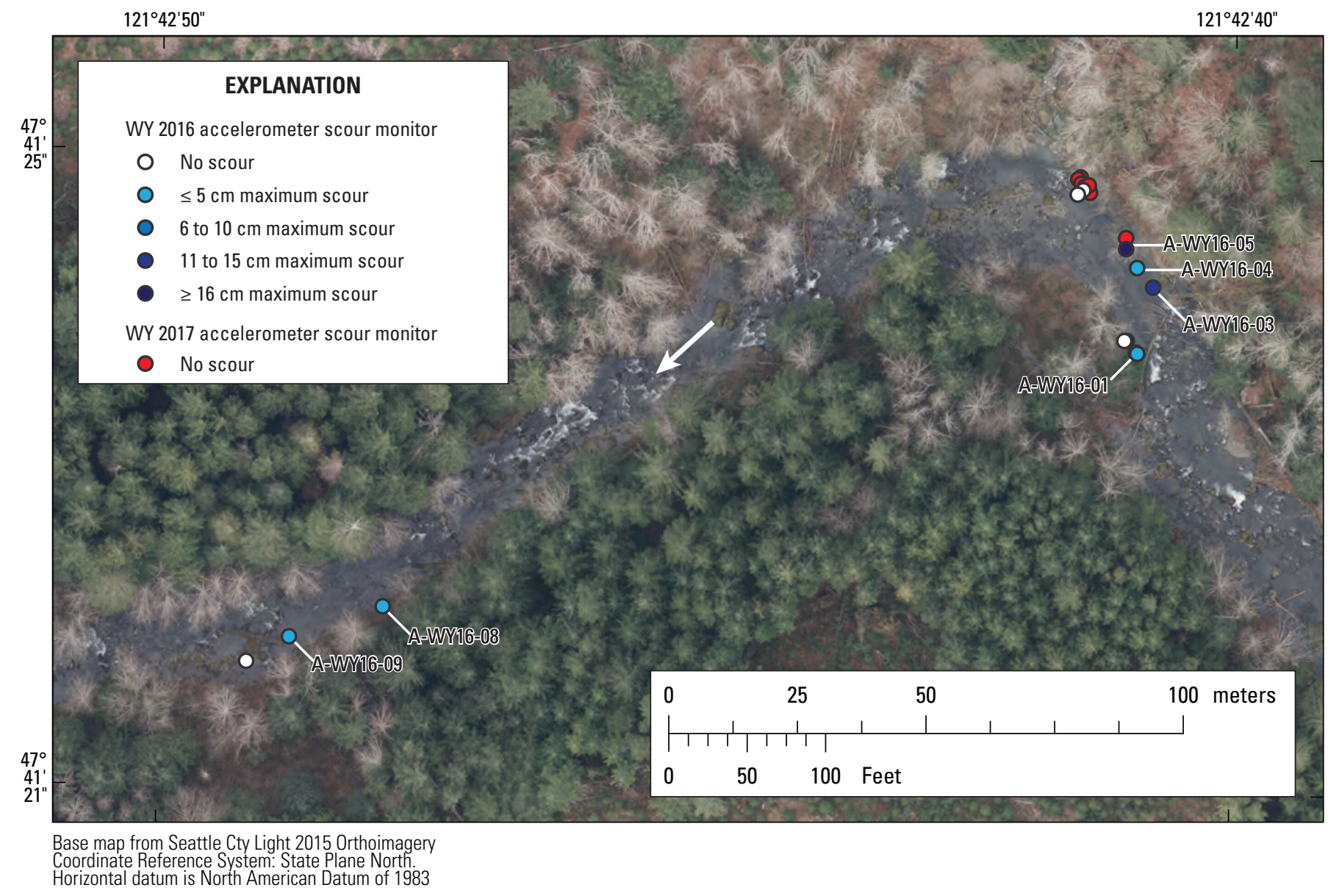

Figure 7. Distribution of accelerometer scour monitors (ASMs) deployed 2017 in reaches $A-D(A-D)$, South Fork Tolt River, King County, Washington, water years 2016 and 2017. [Temporal information for ASMs is in table 1 for 2016 and table 2 for 2017.] 
Reach $B$

$121^{\circ} 45^{\prime} 0^{\prime \prime}$

$121^{\circ} 44^{\prime} 50^{\prime \prime}$

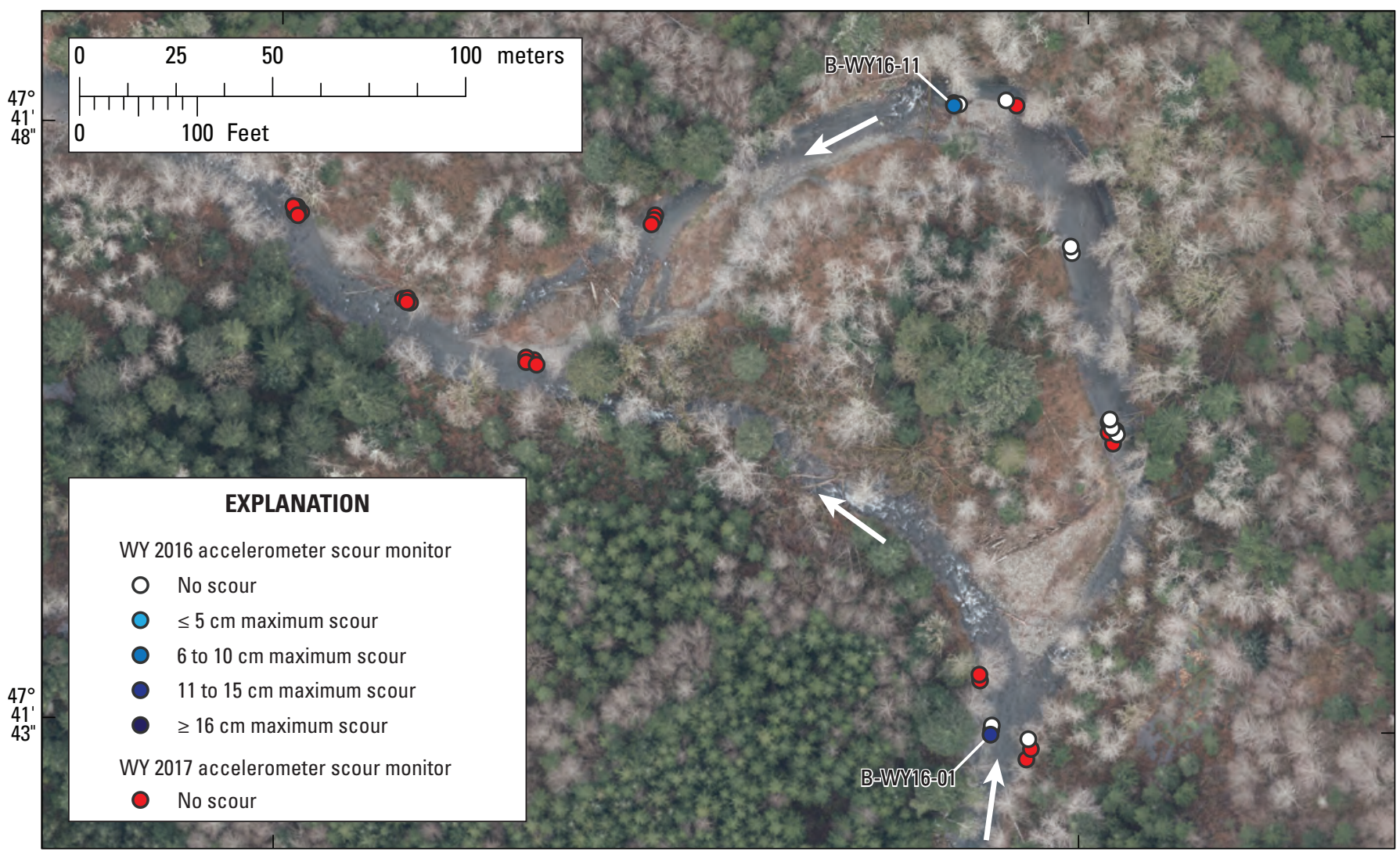

Base map from Seattle Cty Light 2015 Orthoimagery

Coordinate Reference System: State Plane North.

Horizontal datum is North American Datum of 1983

Figure 7. - Continued 
Reach C

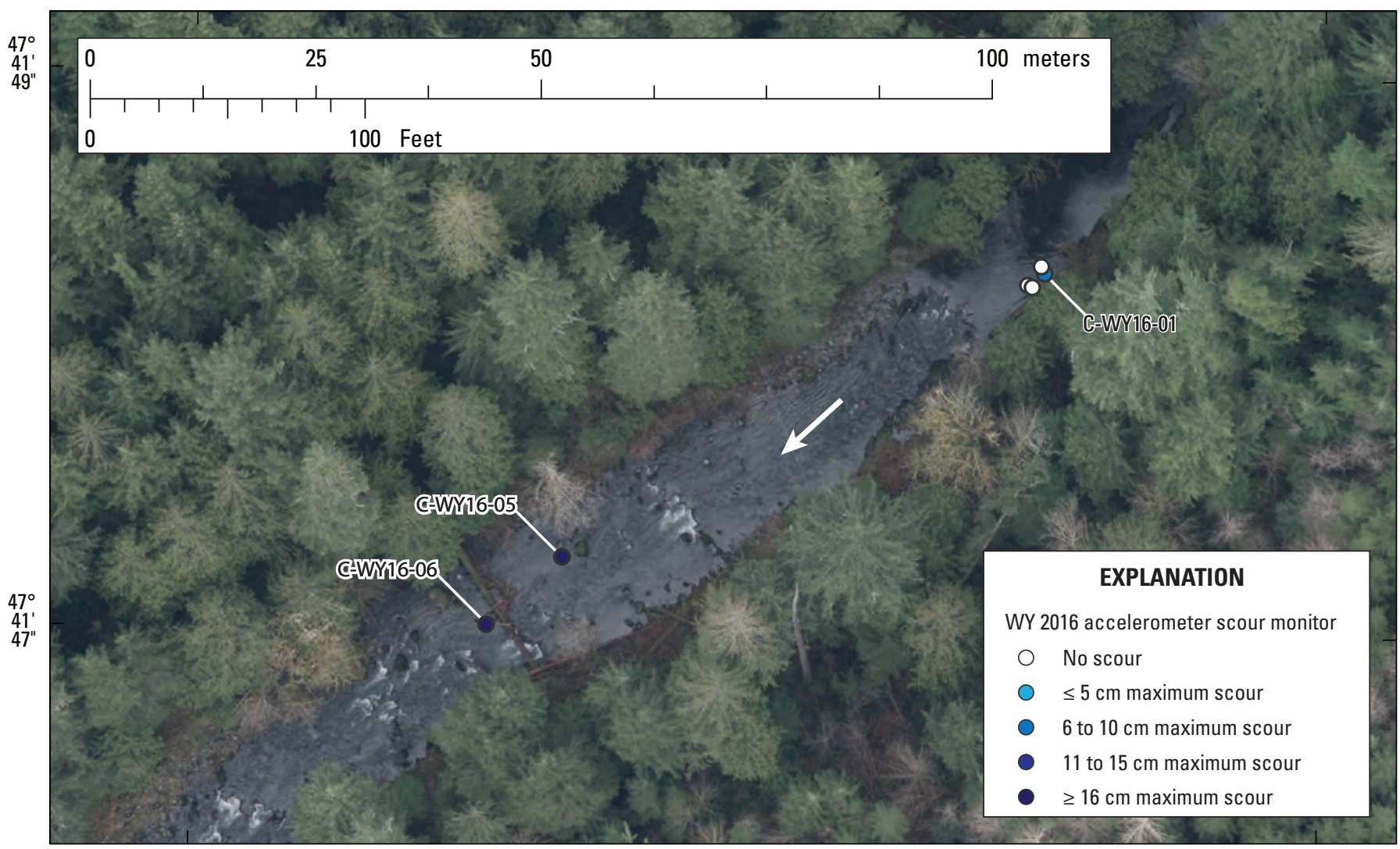

Base map from Seattle Cty Light 2015 Orthoimagery Coordinate Reference System: State Plane North.

Horizontal datum is North American Datum of 1983

Figure 7. - Continued 


\section{Reach D}

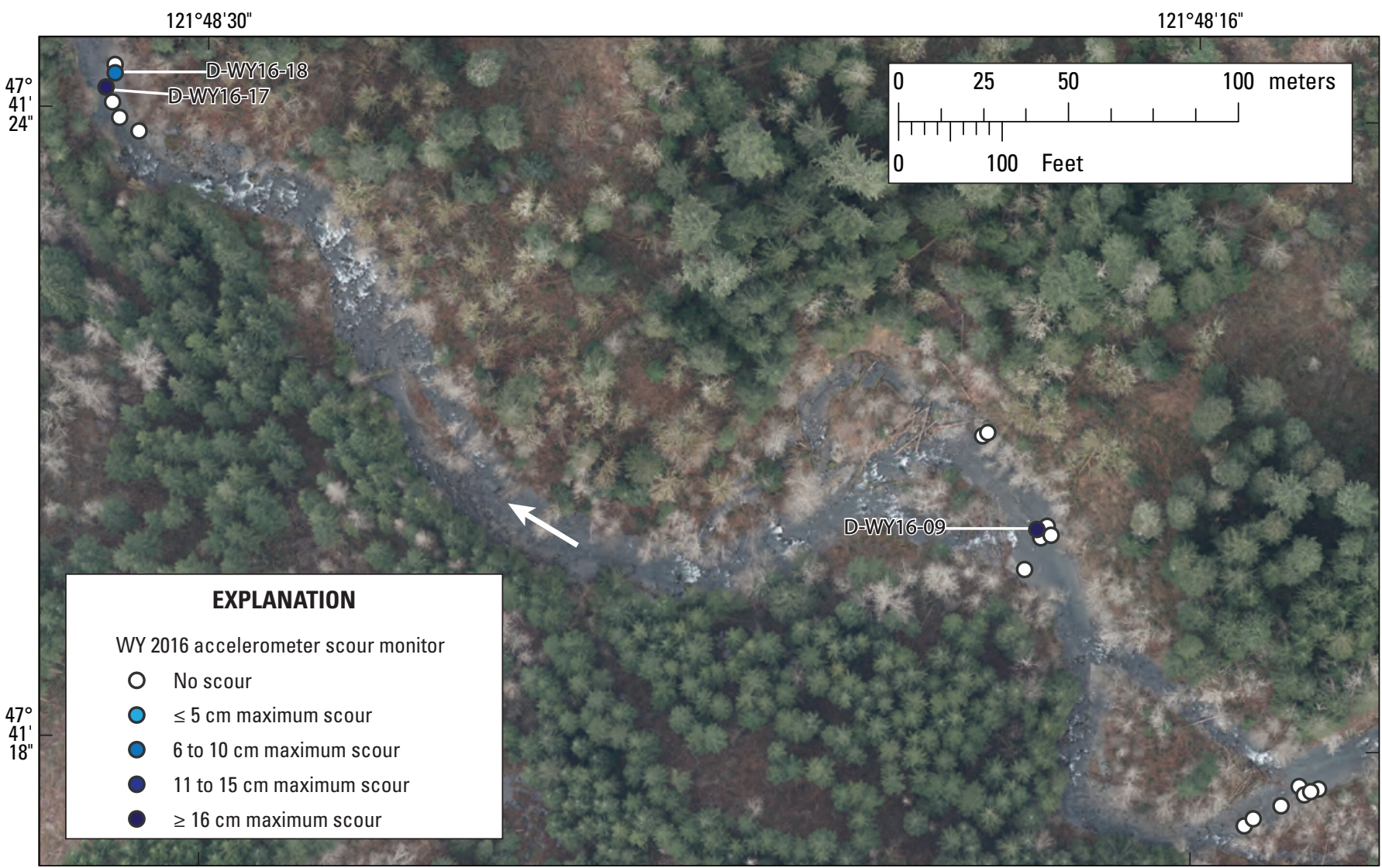

Base map from Seattle Cty Light 2015 Orthoimagery Coordinate Reference System: State Plane North. Horizontal datum is North American Datum of 1983

Figure 7. - Continued

\section{Summary}

Deployments of ASMs during WY 2016 and WY 2017 in four reaches of the South Fork Tolt River revealed that the discharge at which redd scour occurs was greater than previously established operational thresholds. Prior to this study, operational thresholds for peak discharge on the South Fork Tolt River were $350 \mathrm{cfs}$ in the upper part of the river and $550 \mathrm{cfs}$ in the lower part of the river as measured at USGS streamgages 12148000 and 12148300 , respectively. During WY 2016, scour due to sediment transport during high-flow events occurred when discharge equaled or exceeded $969 \mathrm{cfs}$ as measured at USGS streamgage 12148300 . Scour due to sediment transport was not measured during high-discharge events in WY 2017 when maximum discharge was $809 \mathrm{cfs}$ as measured at USGS streamgage 12148300 . This lack of measured scour during WY 2017 was consistent with the minimum discharge when scour was observed in WY 2016. Although scour during high-flow events was not measured in WY 2017, ASM movements recorded during WY 2017 provided information about the timing of fish spawning recorded between high-flow events.

\section{Acknowledgments}

The authors thank the Tolt Fisheries Advisory Committee for their help developing the scope and themes of this study and locating salmonid spawning habitat. The authors also thank staff from Seattle City Light, Seattle Public Utilities, the Tulalip Tribes, and the Washington State Department of Ecology for help deploying and retrieving accelerometer scour monitors and providing logistical support. 


\section{References Cited}

Burner, C.J., 1951, Characteristics of spawning nests of Columbia River salmon-U.S. Fish and Wildlife Service: Fish Bulletin, v. 61, p. 97-110.

DeVries, P., 1997, Riverine salmonid egg burial depthsReview of published data and implications for scour studies: Canadian Journal of Fisheries and Aquatic Sciences, v. 54, no. 8 , p. $1685-1698$.

DeVries, P., Burges, S.J., Daigneau, J., and Stearns, D., 2001, Measurement of the temporal progression of scour in a pool-riffle sequence in a gravel bed stream using an electronic scour monitor: Water Resources Research, v. 37, no. $11, \mathrm{p}$.

Dragovich, J.D., Anderson, M.L., Mahan, S.A., MacDonald, J.H., Jr., and McCabe, C.P., Cakir, Recep, Stoker, B.A., Villeneuve, N.M., Smith, D.T., and Bethel, J.P., 2012, Geologic map of the Lake Joy 7.5-minute quadrangle, King County, Washington: Washington Division of Geology and Earth Resources Map Series 2012-01, 2 sheets, scale $1: 24,000,79 \mathrm{p}$.

Emmett, W.W., and Leopold, L.B., 1965, Downstream patterns of riverbed Scour and fill: U.S. Department of Agriculture, Proceedings of the Federal Inter-Agency Sedimentation Conference, vol. 1, 963, Misc. Publ. U.S. Dep. Agric. 970, p. 399-409.

Gendaszek, A.S., Burton, K., Magirl, C.S., and Konrad, C.P., 2018, Streambed scour of salmon spawning habitat in a regulated river influenced by management of peak discharge: Freshwater Biology, v. 63, no. 8, p. 917-927.

Gendaszek, A., Czuba, C.R., Magirl, C.S., and Konrad, C.P., 2013, The timing of scour and fill in a gravel-bedded river measured with buried accelerometers: Journal of Hydrology (Amsterdam), v. 495, p. 186-196.

Gendaszek, A.S., 2020, Accelerometer scour monitor data on the South Fork Tolt River, Washington, Water Year 2016-2017: U.S. Geological Survey data release, https:// doi.org/10.5066/P9856N6Z.
Klassen, H.D., and Northcote, T.G., 1986, Stream bed configuration and stability following gabion weir placement to enhance salmonid production in a logged watershed subject to debris torrents: Canadian Journal of Forest Research, v. 16 , no. 2 , p. 197-203.

May, C.L., Pryor, B., Lisle, T.E., and Lang, M., 2009, Coupling hydrodynamic modeling and empirical measures of bed mobility to predict the risk of scour and fill of salmon redds in a large regulated river: Water Resources Research, v. 45 , no. 5 , W05402.

Montgomery, D.R., Buffington, J.M., Peterson, N.P., SchuettHames, D., and Quinn, T.P., 1996, Stream-bed scour, egg burial depths, and the influence of salmonid spawning on bed surface mobility and embryo survival: Canadian Journal of Fisheries and Aquatic Sciences, v. 53, no. 5, p. 1061-1070.

Neiman, P.J., Schick, L.J., Ralph, F.M., Hughes, M., and Wick, G.A., 2011, Flooding in western Washington-The connection to atmospheric rivers: Journal of Hydrometeorology, v. 12 , no. 6 , p. $1337-1358$.

PRISM Climate Group, 2014, 30-year normals data: PRISM Climate Group data, Oregon State University, accessed July 31, 2017, at http://www.prism.oregonstate.edu/normals/

Thorne, R.E., and Ames, J.J., 1987, A note on variability of marine survival of sockeye salmon (Onchorhynchus nerka) and effects of flooding on spawning success - Canadian Journal of Fisheries and Aquatic Sciences 44, 1791-1795: Water Resources Research, v. 45, W05402.

U.S. Geological Survey, 2019, National Water Information System: U.S. Geological Survey web interface, accessed June 20, 2019, at https://waterdata.usgs.gov/nwis.

Whiting, P.J., Stamm, J.F., Moog, D.B., and Orndorff, R.L., 1999, Sediment-transporting flows in headwater streams: Geological Society of America Bulletin, v. 111, no. 3, p. $450-466$.

Wolman, M.G., 1954, A method of sampling coarse river-bed material: Transactions - American Geophysical Union, v. 35 , no. 6 , p. $951-956$. 
Publishing support provided by the U.S. Geological Survey Science Publishing Network, Tacoma Publishing Service Center

For more information concerning the research in this report, contact the Director, Washington Water Science Center

U.S. Geological Survey

934 Broadway, Suite 300

Tacoma, Washington 98402

https://www.usgs.gov/centers/wa-water 


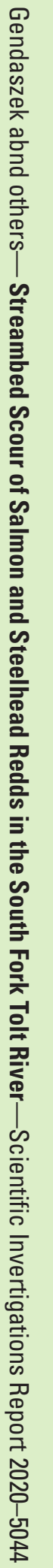

